\title{
Implikasi Dissenting Opinion Hakim Mahkamah Konstitusi Terhadap Kesadaran Hukum Masyarakat
}

\author{
Muhamad Rusdi \\ Fakultas Hukum Universitas Widya Mataram \\ Ndalem Mangkubumen KT III/237 Yogyakarta 55132, Indonesia \\ rusdi.rs@gmail.com
}

\begin{abstract}
This study examines the dissenting opinion in Decision Number 138/PUU-VII/2009, at the time of the material test. So that the difference of opinion has implications for two things, namely; first, providing freedom for every judge to explore, follow, and understand the legal values and sense of justice that lives in society. Secondly, it becomes an evaluation material and study for the community to map judges' decisions which are based on procedural justice and substantive justice. The Constitutional Court's dissenting judge's opinion on its development affected the level of public legal awareness, so that with the dissenting opinion paradigm the public thought about the independence of judges could bring quality decisions. This study uses the interpretive paradigm with descriptive qualitative methods. The source of this research is the decision of the Constitutional Court (Decision Number 138/PUU-VII/2009) which is correlated with the legislation governing the Constitutional Court dissenting opinion judge. The problem analysis in this study uses a legal political approach and two theories, namely the authority theory and teleology theory.
\end{abstract}

Keywords: Constitutional Court, Dissenting Opinion, Legal Awareness

\begin{abstract}
Abstrak
Penelitian ini mengkaji mengenai dissenting opinion dalam Putusan Nomor 138/PUU-VII/2009, pada saat uji materi. Sehingga perbedaan pendapat tersebut berimplikasi terhadap dua hal, yaitu; pertama, memberikan keleluasaan bagi setiap hakim untuk menggali, mengikuti, dan memahami nilai-nilai hukum dan rasa keadilan yang hidup dalam masyarakat.Kedua, menjadi bahan evaluasi dan kajian bagi masyarakat untuk memetakan putusan-putusan hakim yang memang didasarkan terhadap keadilan prosedural dan keadilan substantif.Dissenting opinion hakim Mahkamah Konstitusi dalam perkembangannya berpengaruh terhadap tingkat kesadaran hukum masyarakat, sehingga dengan adanya dissenting opinion paradigma berpikir masyarakat tentang independensi hakim dapat memunculkan putusan yang berkualitas.Penelitian ini menggunakan paradigma interpretatif dengan metode kualitatif deskriptif.Sumber dari penelitian ini adalah putusan Mahkamah Konstitusi (Putusan Nomor138/PUU-VII/2009) yang dikorelasikan dengan peraturan perundang-undangan yang mengatur mengenai dissenting opinion hakim Mahkamah Konstitusi.Analisis permasalahan dalam penelitian ini menggunakan pendekatan politik hukum dan dua teori, yaitu teori kewenangan dan teori teleologi.
\end{abstract}

Kata Kunci: Mahkamah Konstitusi, Dissenting Opinion, Kesadaran Hukum

\section{A. Pendahuluan}

Suatu negara yang menyatakan dirinya sebagai negara hukum (termasuk Indonesia sebagaimana Pasal 1 Ayat (3) Undang-Undang Dasar Negara Republik Indonesia Tahun 1945), akan melahirkan beberapa konsekwensi yang tidak dapat dihindari diantaranya; pertama; adanya penegakan hukum, kedua; perlunya jaminan 
mengenai independensi lembaga penegak hukum, Ketiga; kualitas produk perundang-undangan harus baik. Ketiga hal tersebut merupakan komponen penting dalam membangun negara hukum, yang didasarkan atas cita-cita bangsa (rechtsidee).

Lembaga penegak hukum sebagaimana dimaksud adalah lembaga peradilan yang merdeka untuk menyelenggarakan peradilan guna menegakkan hukum dan keadilan. ${ }^{1}$ Diantara peradilan yang masuk dalam lingkungan kekuasaan kehakiman adalah Mahkamah Konstitusi (MK) yang berwenang mengadili pada tingkat pertama dan terakhir yang putusannya bersifat final dan mengikat untuk menguji Undang-Undang terhadap Undang-Undang Dasar, memutus sengketa kewenangan lembaga negara yang kewenangannya diberikan oleh Undang-Undang Dasar, memutus pembubaran partai politik, dan memutus perselisihan tentang hasil pemilihan umum. ${ }^{2}$

Secara gramatikal, kewenangan Mahkamah dalam menguji undang-undang terhadap Undang-Undang Dasar tertuang dengan jelas telah diatur dalam UndangUndang Dasar NRI Tahun 1945. Dengan demikian, Mahkamah tidak mempunyai kewenangan menguji dan memutus diluar ketentuan Pasal 24C UUD 1945 (termasuk Peraturan Pemerintah Pengganti Undang-undang atau Perppu). Pada tahun 2009 Mahkamah telah menerima uji materi Pasal 33A dan Pasal 33B Peraturan Pemerintah Pengganti Undang-Undang No. 24 Tahun 2009 tentang Perubahan Atas Undang-undang Nomor 30 Tahun 2002 tentang Komisi Pemberantasan Tindak Pidana Korupsi, yang dimohonkan oleh Saor Siagian, SH., dkk. Permohonan tersebut dalam pertimbangan Mahkamah tidak berkaitan dengan legal standing pemohon sehingga, permohonan tidak dapat diterima.

Walaupun permohonan tidak dapat diterima oleh Mahkamah Konstitusi, namun terjadi dissenting opinion (pendapat berbeda) dari Hakim Muhammad Alim. Dissenting opinion Hakim Mahkamah Konstitusi telah dijamin dalam Pasal 45 Ayat (1) UU No. 24 Tahun 2003 tentang Mahkamah Konstitusi, bahwa pendapat anggota Majlis Hakim yang berbeda dimuat dalam putusan. Diaturnya dissenting opinion dalam undang-undang merupakan bentuk penegasan dari independensi

${ }^{1}$ Pasal 24 Ayat (1)Undang-Undang Dasar 1945

${ }^{2}$ Pasal 24C Ayat (1) 
hakim yang tidak dapat di intervensi meskipun oleh internal peradilan, hal ini melengkapi kebebasan pilihan hakim untuk mengatur organisasi, personalia, administrasi, dan keuangan sesuai dengan prinsip pemerintahan yang baik dan bersih. $^{3}$

Dissenting opinion tidak hanya mengenai independensi Hakim yang nantinya berimplikasi terhadap kualitas putusan para hakim, namun dalam perkembannya juga mendorong tingkat kesadaran hukum masyarakat di Indonesia. Untuk menjawab permasalahan yang akan diteliti, Pendekatan yang dipilih adalah politik hukum dengan menggunakan dua teori yaitu, teori kewenangan dan teori teleologi. Pendekatan dan teori yang menjadi dasar untuk mengetahui sejauh mana Putusan Nomor 138/PUU-VII/2009.

\section{B. Telaah Konsep}

Pengertian Implikasi dalam penelitian ini adalah suatu dampak dari adanya dissenting opinion atau Perbedaan pendapat dalam Putusan Nomor 138/PUUVII/2009, yang mempengaruhi tingkat kesadaran hukum masyarakat. Sedangkan pengertian dissenting opinion secara normatif telah diatur salah satunya melalui Pasal 45 ayat (10) UU No. 24 Tahun 2003 tentang Mahkamah Konstitusi, yang menyebutkan:" dalam hal putusan tidak tercapai mufakat bulat, pendapat anggota Majelis Hakim yang berbeda dimuat dalam putusan". Dissenting opinionmenurut Jimly Asshiddiqie, adalah pendapat yang berbeda secara substantif sehingga menghasilkan amar yang berbeda. ${ }^{4}$

Yang dimaksud dengan Hakim Mahkamah Konstitusi adalah yang sebagaimana yang dimaksud dalam Pasal 24C UUD 1945, yaitu hakim disuatu lembaga bernama Mahkamah Konstitusi. Sedangkan yang dimaksud dengan kesadaran hukum dalam penelitian ini, adalah suatu kesadaran masyarakat yang muncul setelah adanya Putusan Nomor 138/PUU-VII/2009.

Berdasarkan latar belakang masalah tersebut, dapat disimpulkan rumusan masalah sebagai berikut.Pertama; Apa yang menyebabkandissenting opiniondalam

\footnotetext{
${ }^{3}$ Pasal 12 UU No. 23 Tahun 2003 tentang Mahkamah Konstitusi

${ }^{4}$ Jimly Asshiddiqie.2006."'Hukum Pengujian Undang-undang”.Penerbit Sekjen dan Kepaniteraan MK RI.Jakarta.Cetakan Kedua.hlm.289
} 
Putusan Nomor 138/PUU-VII/2009?, kedua; Mengapa Dissenting Opinionberpengaruh terhadap kesadaran hukum masyarakat?, ketiga; Bagaimana penegakan hukum setelah adanyaDissenting Opiniondalam Putusan Nomor 138/PUU-VII/2009?

\section{Metode Penelitian}

Jenis penelitian yang digunakan disini bersifat deskriptif yang bertujuan untuk memperoleh suatu gambaran secara normatif mengenai suatu penegakan hukum yang didasarkan atas Pasal 24C ayat (1) UUD 1945, mengenai wewenang Mahkamah Konstitusi dalam memutus uji materi undang-undang terhadap UUD 1945. Dalam uji materi tersebut menimbulkan dua peristiwa yakni adanya dissenting opinion dan consenting opinion dari dua hakim yang berbeda (Putusan Mahkamah Konstitusi Nomor 138/PUU-VII/2009). Adanya perbedaan pandangan tersebut tentu berimplikasi terhadap tingkat kesadaran hukum masyarakat di Indonesia karena, penegak hukum berpotensi mengacu terhadap adanya dissenting opinion yang muncul dari salah satu hakim sehingga, dua pandangan hakim yang berbeda dapat membingungkan para penegak hukum dan masyarakat karena sama-sama mempunyai kekuatan hukum.

Perundang-undangan (Statutory Approach) dan pendekatan kasus (The Case Approach). Pendekatan perundangan-undangan ialah pendekatan yang dilakukan dengan menelaah undang-undang.Hasil analisis data kemudian disimpulkan sehingga menghasilkan gambaran secara jelas dan memperoleh jawaban dari permasalahan yang dirumuskan.

Adapun logika penarikan kesimpulan dalam penelitian ini menggunakan teknik analisis norma yang dihubungkan dengan putusan hakim Mahkamah Konstitusi (Nomor 138/PUU-VII/2009) dengan logika deduktif. Logika deduktif atau pengolahan bahan hukum dengan cara deduktif yaitu menjelaskan bahwa suatu hal yang bersifat umum kemudian ditarik menjadi kesimpulan yang lebih khusus. ${ }^{5}$

${ }^{5}$ Maria SW. Sumardjono, 2014, Metodologi Penelitian Ilmu Hukum, Gadjah Mada Press, Yogyakarta, hlm. 16-25. 


\section{Pembahasan}

Kekuasaan kehakimanyang berlaku pada suatu Negara hukum, merupakan salah satu badan yang sangat menentukan isi dari kaidah-kaidah hukum positif dalam kongkritisasinya oleh hakim pada putusan-putusannya di depan Pengadilan. Dengan ungkapan lain bahwa, sebaik apapun peraturan hukum yang diciptakan yang bertujuan untuk menjamin keselamatan masyarakat menuju kesejahteraan rakyat, maka peraturan tersebut tidak ada artinya apabila tidak ada kekuasaan kehakiman yang dapat mengisi kekuatan norma tersebut. Disinilah salah satu fungsi dari bada peradilan yang menjadi tempat untuk menjadi keadilan bagi masyarakat atau menyelesaikan persoalan-persoalan mengenai hak dan kewajibannya menurut hukum. ${ }^{6}$

Pasal 24 ayat (1) Undang-Undang Dasar 1945 menyebutkan bahwa kekuasaan kehakiman mempunyai kekuasaan yang merdeka yang bertujuan untuk menegakkan hukum dan keadilan.Mahkamah Konstitusi sebagai salah satu lembaga peradilan yang mempunyai kekuasaan kehakiman sebagaimana disebut dalam Pasal 24C ayat (1) Undang-Undang Dasar 1945, mempunyai wewenang untuk mengadili pada tingkat pertama dan terakhir yang salah satu kewenangannya adalah menguji undang-undang terhadap Undang-Undang Dasar.

Kemerdekaan hakim Mahkamah Konstitusi untuk memutuskan suatu permohonan diatur dalam Pasal 45,46,47,48, dan 49 Undang-undang Nomor 24 tahun 2003 tentang Mahkamah Konstitusi. Kemerdekaan dalam memutus suatu permohonan tidak hanya mempunyai kemerdekaan yang sifatnya eksternal (tidak terpengaruh dari pihak-pihak diluar pengadilan) namun dalam internal pengadilan, ketika para hakim dalam bermusyawarah untuk memutuskan suatu permohonan dapat berbeda pendapat. Perbedaan pendapat dalam memutus suatu permohonan terdapat dalam Pasal 45 Undang-undang Nomor 24 tahun 2003 tentang Mahkamah Konstitusi sebagaimana disebutkan:

${ }^{6}$ I Gede Yusa (Editor).2011."Demokrasi HAM, \& Konstitusi: Perspektif Negara-Bangsa untuk Menghadirkan Keadilan”. Kado untuk Sang Guru Prof. Dr. I Dewa Gede Atmadja.Setara Press.Malang.hlm. 80 
1. Dalam hal musyawarah sidang pleno Hakim Konstitusi (sebagaimana dimaksud ayat (4)) tidak dapat menghasilkan putusan, musyawarah ditunda sampai musyawarah sidang pleno Hakim Konstitusi berikutnya (ayat (6)).

2. Dalam hal musyawarah sidang pleno setelah diusahakan dengan sungguhsungguh tidak dapat dicapai mufakat bulat, putusan diambil dengan suara terbanyak (ayat (7)).

3. Dalam hal musyawarah sidang pleno hakim kontitusi sebagaimana dimaksud pada ayat (7) tidak dapat diambil dengan suara terbanyak, suara terakhir ketua sidang pleno hakim konstitusi menentukan (ayat (8)).

4. Dalam hal putusan tidak tercapai mufakat bulat sebagaimana dimaksud pada ayat (7) dan ayat (8), pendapat anggota Majelis Hakim yang berbeda dimuat dalam putusan (ayat (10)).

Pasal tersebut memberikan keleluasaan terhadap hakim Mahkamah Konstitusi yang mempunyai perbedaan pendapat dalam memutus suatu perkara sehingga, masing-masing hakim dapat memberikan pertimbangan-pertimbangan tanpa terikat dengan siapapun dan kepada apapun (keculai terhadap keadilan). Kebebasan hakim Mahkamah Konstitusi dalam memutuskan suatu permohonan dibuktikan ketika mengeluarkan Putusan salah satunya adalah Putusan Nomor 138/PUU-VII/2009 pada 8 Februari tahun 2010, putusan tersebut adalah pengujian Mahkamah Konstitusi terhadap Peraturan Pemerintah Pengganti Undang-undang Nomor 4 tahun 2009 tentang Perubahan Atas Undang-Undang Nomor 30 tahun 2002 tentang Komisi Pemberantasan Tindak Pidana Korupsi. ${ }^{7}$

\section{Dalam pengujian Peraturan Pemerintah Pengganti Undang-Undang} Nomor 4 tahun 2009, Putusan Mahkamah Konstitusi (Nomor 138/PUUVII/2009) alasan berbeda dari Hakim Mahfud MD dan pendapat berbeda dari Hakim Muhamad Alim. Menurut Jimly Asshiddiqie, hakim Mahfud MD yang berbeda pendapat namun menyetujui disebut dengan consenting opinion atau concurrent opinion, sedangkan pendapat hakim Muhammad Alim disebut dengan dissenting opinion. ${ }^{8}$

\footnotetext{
${ }^{7}$ Achmad Edi Subiyanto.2014.”Yurisprudensi Hukum Acara dalam Putusan Mahkamah Konstitusi".(Penyunting).Setara Press.Malang.hlm.40

${ }^{8}$ Jimly Asshiddiqie.2006. "Hukum Acara...,Op., Cit.hlm.289-290
} 
Dasar hukum mengenai perbedaan pendapat Hakim Mahkamah Konstitusi diatur dalam Pasal 45 UU No. 24 tahun 2003 Tentang Mahkamah Konstitusi, Pasal tersebut menyebutkan:

a. Dalam hal musyawarah sidang pleno setelah diusahakan dengan sungguhsungguh tidak dapat dicapai mufakat bulat, putusan diambil dengan suara terbanyak (Ayat (7)).

b. Dalam hal musyawarah sidang pleno hakim konstitusi sebagaimana dimaksud pada ayat (7) tidak dapat diambil suara dengan suara terbanyak, suara terakhir ketua sidang pleno hakim konstitusi menentukan (Ayat (8)).

c. Dalam hal putusan tidak tercapai mufakat bulat sebagaimana dimaksud pada ayat (7) dan ayat (8), pendapat anggota Majelis Hakim yang berbeda dimuat dalam putusan (Ayat (10)).

Perbedaan pendapat diantara hakim semata-mata karena perbedaan pandangan dalam menerapkan hukum melalui kewenangan yang diberikan terhadap Mahkamah Konstitusi. Menurut Radbruch (1946), putusan hakim yang ideal adalah apabila mengandung unsur-unsur Gerechtigkeit (keadilan), Zweckmassigkeit (kemanfaatan), dan Rechtssicherheit (kepastian hukum) secara proporsional. ${ }^{9}$ Menurut Prof. Kusumadi Pudjosewojo, keputusan hakim dapat dibagi menjadi 3 (tiga) yaitu; Pertama, pertimbangan-pertimbangan tentang kenyataan-kenyataan yang didapati oleh hakim setelah memeriksa perkara.Kedua, pertimbangan-pertimbangan tentang hukum dalam perkara yang ditemukan oleh hakim, harus berdasarkan kenyataan-kenyataan atau fakta-fakta yang ditemukan oleh hakim.Ketiga, keputusannya atau diktum.

Keputusan hakim harus adil serta harus bermanfaat bagi yang bersangkutan maupun bagi masyarakat, dan terjamin kepastian hukum bagi yang berperkara atau pemohon (masyarakat).Pada praktiknya, tidak mungkin untuk menghadirkan ketiga unsur Idee des Rechts itu secara proporsional dalam suatu putusan.Sering terjadi ketegangan atau konflik antara ketiga unsur (Gerechtigkeit, Zweckmassigkeit, dan rechtssicherheit), ketegangan tersebut adalah sebuah tuntutan bagi hakim untuk

${ }^{9}$ Sudikno Mertokusumo.2011.”Teori Hukum ’.Universitas Atma Jaya.Yogyakarta.hlm.23 
menemukan sebuah seni agar tidak terjadi ketegangan. ${ }^{10}$ Kepastian hukum merupakan perlindungan yustisiabel (warga masyarakat yang mendapatkan hukuman) dari tindakan yang sewenang-wenang, dengan kepastian hukum masyarakat akan lebih tertib karena adanya kejelasan dalam kedudukan hak dan kewajibannya menurut hukum dan tujuannya adalah tercapainya ketertiban masyarakat. ${ }^{11}$

Dalam Putusan Nomor 138/PUU-VII/2009, perbedaan argumentasi dari dua hakim (Mahfud MD dan Muhammad Alim) adalah sebagai berikut;

1. Hakim Mahkamah Konstitusi Mahfud MD berpendapat bahwa, Dalam kaitan antara perkembangan ketatanegaraan dan pengujian Peraturan Pemerintah Pengganti Undang-undang ini saya melihat perlunya penafsiran atas isi Undang-Undang Dasar 1945 tidak hanya bertumpu pada original intent, tafsir historis, dan tafsir gramatik melainkan harus menekankan pada penafsiran sosiologis dan teleologis. Diantara alasan tersebut adalah:

a. Kalau Perpu tidak dapat diuji oleh Mahkamah maka sangat mungkin suatu saat ada Perpu yang dikeluarkan tetapi DPR tidak membahasnya dengan cepat dan mengulur-ulur waktu dengan berbagai alasan, padahal Perpu tersebut mengandung hal-hal yang bertentangan dengan konstitusi.

b. Ada ketidak pastian waktu, sampai berapa lama atau kapan Perpu yang tidak mendapat persetujuan DPR harus diganti dengan UndangUndang Pencabutan atau Undang-Undang Pengganti.

2. Hakim Mahkamah Konstitusi Hakim Muhammad Alim mempunyai 7 (tujuh) alasan sebagai dasar argumentasinya, sehingga tetap pada pendiriannya yaitu Mahkamah Konstitusi tidak berwenang mengadili permohonan a quo. Diantara alasannya adalah;

a. Pasal 24C ayat (1) Undang-Undang Dasar 1945, Pasal 10 ayat (1) huruf a Undang-Undang Nomor 24 Tahun 2003 tentang Mahkamah

\footnotetext{
${ }^{10}$ Ibid.

${ }^{11}$ A. Mukthie Fadjar.2008. "Sang Penggembala, Perjalanan Hidup dan Pemikiran Hukum A. Mukthie Fadjar (Hakim Konstitusi Periode 2003-2008)'.Penerbit Sekretariat Jenderal dan Kepaniteraan Mahkamah Konstitusi.Jakarta.hlm.270
} 
Konstitusi, Pasal 12 ayat (1) huruf a Undang-Undang Nomor 4 Tahun 2004 tentang Kekuasaan Kehakiman hanya menyebut, "Menguji undang-undang terhadap UUD".

b. Pasal 20 Undang-Undang Dasar 1945, yaitu kewenangan membentuk undang-undang, begitu pula Pasal 22A tentang kewenangan membuat Perpu, sudah lebih dahulu ada, karena waktu mengubah Pasal 20 UUD 1945 dilakukan pada Perubahan Pertama (1999) dan khusus ayat (5) pada Perubahan Kedua (2000); Pasal 22 UUD 1945 tidak ada perubahan, sedangkan Pasal 24C ayat (1) dilakukan pada Perubahan Ketiga (2001), tetapi hanya menyebut, "Menguji undang-undang terhadap Undang-Undang Dasar;"

Perbedaan pendapat dua hakim (Mahfud MD dan Muhammad Alim) disebabkan dalam Undang-Undang Dasar 1945 tidak disebutkan bahwa, Mahkamah Konstitusi dapat menguji Peraturan Pemerintah Pengganti Undangundang. Dengan begitu, Mahkamah Konstitusi dalam melakukan pengujian tidak sesuai dengan ketentuan yang diatur dalam Undang-Undang Dasar 1945. Menurut Roland Dworkin, Mahkamah Konstitusi telah menerapkan judicial discretion. Dengan judicial discretion, positive legislature bukan berarti Mahkamah Konstitusi memiliki kewenangan legislature sebagaimana lembaga legislatif membuat Undang-undang. ${ }^{12}$

\section{Implikasi Dissenting Opinion Hakim Mahkamah Konstitusi}

Putusan Mahkamah Konstitusi dalam perkembangannya menurut Martitah telah mengalami pergeseran fungsi yaitu dari negative legislature (hanya memutuskan) ke positive legislature (keputusan yang sifatnya mengatur), putusan tersebut biasanya didasarkan pada 3 (tiga) pertimbangan yaitu; (1).Untuk menciptakan keadilan dan kemanfaatan masyarakat, (2). Adanya situasi yang mendesak, dan (3). Mengisi rechtvacuum, yaitu untuk menghindari chaos atau kekacauan hukum dalam masyarakat. $^{13}$

\footnotetext{
${ }^{12}$ Martitah.2013." Mahkamah Konstitusi dari Negative legislature ke Positive Legislature”.Konstitusi Press.Jakarta.hlm.175

${ }^{13}$ Ibid.hlm. 170
} 
Namun dengan adanya dissenting opinion dari Hakim Mahkamah Konstitusi Muhammad Alim yang menggunakan pertimbangan yuridis-normatif, mempunyai perberbedaan kesimpulan dengan Hakim Mahkamah Konstitusi Mahfud MD yang menggunakan pertimbangan original intent, tafsir historis, dan tafsir gramatik, namun juga pertimbangan sosiologis, serta teleologis.

Dilihat dari dasar argumentasi dari hakim Muhammad Alim, jika dilihat melalui doktrin positivisme hukum maka, dapat disimpulkan bahwa argumentasi tersebut merupakan doktrin dari positivisme hukum sehingga satu-satunya dasar yang menjadi acuan adalah norma yang berlaku di Indonesia (UUD 1945 amandemen keempat). Berbeda dengan hakim Mahfud MD yang argumentasinya didasarkan terhadap tafsir diantaranya tafsir teleologis dan sosiologis, yang lebih mengedepankan keadilan tanpa harus terikat dengan norma. Karena menurutnya, norma dibuat bertujuan untuk membangun keadilan dan jika keadilan terkendala karena adanya nomr maka, norma tersebut harus diabaikan demi keadilan yang berkembang di masyarakat.

Perbedaan pandangan inilah yang menyebabkan munculnyaDissenting Opinion dan Consenting Opinionsehinggga, dengan adanya dua hal tersebut (Dissenting Opinion dan Consenting Opinion) masyarakat dapat mengkaji perbedaan pandangan dua hakim tersebut.

\section{Implikasi Dissenting Opinion terhadap Penegakan Hukum}

Putusan Mahkamah Konstitusi yang dalam putusannya mengenyampingkan ketentuan dalam Undang-undang tidak hanya terjadi ketika mengeluarkan Putusan Nomor 138/PUU-VII/2009, namun telah dilakukan sejak tahun 2003 melalui Putusan Mahkamah Konstitusi Nomor 004/PUU-I/2003 ketika Mahkmah Konstusi melakukan pengujian terhadap salah satu Pasal dalam pengujian Undang-undang Nomor 14 Tahun 1985 tentang Mahkamah Agung. Pengujian Mahkamah Konstitusi yang mengenyampingkan ketentuan dalam Undang-undang misalnya ketika mengenyampingkan Pasal 50 Undang-Undang Nomor 24 tahun 2003 tentang Mahkamah Konstitusi dalam Pengujian Pasal 7 ayat (1) huruf g Undang-undang Nomor 14 Tahun 1985 tentang Mahkamah Agung. Dengan mengenyampingkan Pasal 50 yang menyebutkan bahwa, Undang-undang yang dapat di mohonkan adalah 
Undang-undang setelah perubahan Undang-Undang Dasar Negara Republik Indonesia tahun 1945 maka, Putusan Mahkamah Konstitusi telah keluar dari yang ditentukan. Menurut Jimly Asshiddiqie, ada 3 (tiga) alasan dalam memutuskan pengujian yang kemudian mengenyampingkan Pasal 50 yaitu; ${ }^{14}$

1. Perkara tersebut telah diregistrasi di MA sebelum Pasal 50 Nomor 24 tahun 2003 tentang Mahkamah Konstitusi berlaku;

2. Mengenyampingkan bukan berarti meniadakan pasal tersebut, dan Mahkamah Konstitusi mengadili berdasarkan Undang-undang Dasar bukan dengan berdasarkan Undang-undang;

3. Berkenaan dengan Peraturan Mahkamah Agung Nomor 2 Tahun 2002 yang menentukan tenggang waktu 90 (sembilan puluh) hari dimaksudkan terhadap undang-undang yang diundangkan setelah Perubahan Undang-Undang Dasar 1945.

Sedangkan dissenting opinion yang muncul dari hakim Muhammad Alim hanya menggunakan alasan yuridis normatif semata, dapat berimplikasi terhadap penegakan hukum yang hanya didasarkan terhadap pertimbangan undang-undang semata sehingga hanya menciptakan keadilan prosedural namun bukan keadilan substantif.Menurut A. Mukthie Fadjar dalam memutus suatu perkara, peradilan atau hakim seharusnya memang tidak hanya mempertimbangkan kepastian hukum semata, namun keadilan adalah tujuan utama baik keadilan substasial maupun keadilan prosedural. $^{15}$

Dalam memutus suatu permohonan, hakim menggunakan metode penafsiran agar dapat menemukan maksud dalam Undang-undang sehingga dapat membuat putusan yang adil bagi pemohon (masyarakat). Menurut Bagir Manan dan Kuntana Magnar, metode penafsiran mempunyai empat macam, diantaranya adalah metode penafsiran otentik atau penafsiran resmi. Penafsiran otentik atau penafsiran resmi adalah penafsiran yang dibuat oleh pembentuk undang-undang. penafsiran resmi mempunyai dua bentuk yaitu, yang terdapat dalam batang tubuh dan yang terdapat

\footnotetext{
${ }^{14}$ Jimly Asshiddiqie.2008."Menegakkan Tiang Konstitusi Memoar Lima Tahun Kepemimpinan Prof. Dr. Jimly Asshiddiqie, S.H. di Mahkamah Konstitusi (2003-2008)'.Penerbit Sekretariat Jenderal dan Kepaniteraan Mahkamah Konstitusi.Jakarta.hlm.165-166

${ }^{15}$ A. Mukthie Fadjar.2008. ”Sang Penggembala...,Op.,Cit.hlm.270
} 
diluar batang tubuh. Dalam melakukan penafsiran terhadap Undang-undang, hakim tidak harus mengikuti penafsiran yang dibuat oleh pembentuk undang-undang. ${ }^{16}$

Sedangkan menurut Wayne LaFavre dalam Sorjono Soekanto, dalam penegakan hukum para penegak hukum lebih tertuju terhadap diskresi. Yang dimaksud dengan diskresi adalah menyangkut pengambilan keputusan yang tidak selalu terikat dengan hukum, namun penilaian pribadi berperan penting dalam penegakan hukum. Diskresi dianggap penting oleh LaFavre disebabkan beberapa hal yaitu: ${ }^{17}$

1. Undang-undang tidak dapat mengatur semua perilaku manusia;

2. Undang-undang tidak dapat menyesuaikan dengan perkembanganperkembangan masyarakat sehingga, Undang-undang dapat menimbulkan ketidakpastian hukum;

3. Dalam penerapan perundang-undangan, materi dapat menjadi kendala sehingga perundang-perundangan tidak dapat terpublikasi dengan maksimal; dan

4. Harus ada kasus-kasus tertentu yang ditangani dengan cara khusus (misalnya kasus yang berkaitan dengan kebutuhan individu).

Dengan mengacu terhadap pertimbangan-pertimbangan berbagai aspek (sosiologis, teleologis dan lain-lain) maka, penegakan hukum yang bertujuan untuk membangun stabilitas kehidupan masyarakat harus dilakukan dengan cepat serta tidak terkendala dengan Undang-undang itu sendiri. Menurut Utrecht, walaupun suatu ketetapan (putusan) bertentangan dengan suatu undang-undang, belum tentu yang demikian disebut bertentangan dengan tujuan atau maksud pembentuk undangundang (automatisch). Hukum yang tercantum dalam undang-undang menurutnya, sebetulnya sistim materiil dari hukum, akan tetapi undang-undang tersebut melanjutkan perkembangannya setelah penetapannya dalam undang-undang tersebut. Oleh sebab itu, dikemudian hari dapat terjadi hal yang dimaksud oleh pembuat

\footnotetext{
${ }^{16}$ Bagir Manandan Kuntana Magnar.1997."Beberapa Masalah Hukum Tata Negara Indonesia".Penerbit Alumni.Edisi Revisi.Bandung.hlm.68

${ }^{17}$ Sorjono Soekanto.2002."Faktor-faktor yang Mempengaruhi Penegakan Hukum”.PT RajaGrafindo Persada.hlm.15
} 
undang-undang berlainan sekali dengan tujuan (sosial) yang baru dari undang-undang (perbedaan ini dapat dibuktikan dengan penafsiran. ${ }^{18}$

\section{Implikasi Dissenting Opinion terhadap Independensi Hakim Mahkamah Konstitusi}

Adanya Dissenting Opiniontidak hanya berdampak terhadap sistem penegakan hukum namun, memberikan ruang kebebasan terhadap hakim untuk menggali dan menerapkan keadilan hukum bagi masyarakat sebagaimana telah diatur dalam UUD 1945, UU No. 48 Tahun 2009 tentang Kekuasaan Kehakiman, UU No. 24 Tahun 2003 tentang Mahkamah Konstitusi serta undang-undang yang berkaitan dengan kekuasaan kehakiman.

Adanya Dissenting Opinionmerupakan salah satu indikator bahwa dalam memutuskan suatu perkara, pada tataran internal hakim (sesama hakim) menunjukkan tidak adanya saling intervensi. Hal ini sesuai dengan Pasal 3 Ayat (1), (2), dan (3) UU No. 48 Tahun 2009;

1. Dalam menjalankan tugas dan fungsinya, hakim dan hakim konstitusi wajib menjaga kemandirian peradilan.

2. Segala campur tangan dalam urusan peradilan oleh pihak lain diluar kekuasaan kehakiman dilarang, kecuali dalam hal-hal sebagaimana dimaksud dalam Undang-Undang Dasar Negara Republik Indonesia Tahun 1945.

3. Setiap orang yang dengan sengaja melanggar ketentuan sebagaimana dimaksud ayat (2) dipidana sesuai dengan ketentuan peraturan perundang-undangan.

Uraian mengenai kemerdekaan hakim diatas (Pasal 3 Ayat (1), (2), dan (3) UU

No. 48 Tahun 2009) menunjukkan bahwa, kemerdekaan hakim perlu mendapatkan legalitas dalam undang-undang agar dalam memutus suatu perkara, hakim tidak diintervensi dan mempengaruhi keputusannya. Bentuk intervensi yang kemudian mempengaruhi hakim dalam memutus perkara, maka akan berpengaruh terhadap pertimbangan hakim yang bisa saja keluar dari konteks keadilan. Dalam Pasal 2 UU No. 24 Tahun 2003, disebutkan;

${ }^{18}$ E. Utrecht.1986. "Pengantar Hukum Administrasi Negara Indonesia”.Pustaka Tinta Mas.Surabaya.hlm.155 
Mahkamah Kontitusi merupakan salah satu lembaga negara yang melakukan kekuasaan kehakiman yang merdeka untuk menyelenggarakan peradilan guna menegakkan hukum dan keadilan.

Kemerdekaan hakim ketika melakukan pengujian terhadap Perpu No. 4 Tahun 2009, terlihat jelas dengan adanya Dissenting Opiniondan Consenting Opinion sebagaimana dijelaskan sebelumnya.

\section{Dari Negative Legislature ke Positive Legislature}

Concurring opinion menurut Ibnu Sina Chandranegara,oleh salah satu hakim yang juga Ketua MK yakni Mahfud MD. Pada substansinya setuju bahwa Mahkamah Konstitusi tidaklah mempunyai kewenangan untuk menguji Perppu, namun dikarenakan menurutnya konstitusi bukanlah suatu produk hukum yang mati, melainkan sebagai suatu the living constitusion, maka ia mempertimbangkan beberapa hal sebelum menyatakan kesetujuannya bahwa MK dapat menguji Perppu dalam Putusan Mahkamah Konstitusi No.138/PUU/2009, sebagai berikut; ${ }^{19}$ pertama,Perppu yang dimohonkan pengujiandalam perkara a quo baru dibahasoleh DPR setelah melampaui masasidang pertama sejak Perppu inidikeluarkan. Seperti diketahui bahwa Perppua quo diundangkan pada tanggal 22September 2009, sedangkan masasidang DPR berikutnya (DPR baru,hasil Pemilu 2009) adalah tanggal1 Oktober sampai dengan tanggal4 Desember 2009, tetapi Perppu aquo tidak dibahas pada masa sidangpertama tersebut. Kalau Perpputidak dapat diuji oleh Mahkamahmaka sangat mungkin suatu saat adaPerppu yang dikeluarkan tetapi DPRtidak membahasnya dengan cepatdan mengulur-ulur waktu denganberbagai alasan, padahal Perpputersebut mengandung hal-hal yangbertentangan dengan konstitusi.Oleh sebab itu menjadi beralasan,demi konstitusi, Perpu harus dapatdiuji konstitusionalitasnya olehMahkamah Konstitusi agar segeraada kepastian dapat atau tidak dapatterus berlakunya sebuah Perppu.

Kedua, Timbul juga polemik tentang adanyaPerppu yang dipersoalkan keabsahanhukumnya karena tidak nyatanyatadisetujui dan tidak nyatanyataditolak oleh DPR. Dalamkasus ini DPR hanya meminta agarPemerintah segera

19 Ibnu Sina Chandranegara. "Pengujian Perppu Terkait Sengketa Kewenangan Konstitusional Antar Lembaga Negara: Kajian Atas Putusan MK Nomor 138/PUU-VII/2009”. Dalam Jurnal Yudisial.Vol. 5 No. 1, April 2012.hlm.9-19 
mengajukanRUU baru sebagai pengganti Perppu.Masalah mendasar dalam kasusini adalah bagaimana kedudukanhukum sebuah Perppu yang tidakdisetujui tetapi tidak ditolak secaranyata tersebut. Secara gramatik, jikamemperhatikan bunyi Pasal 22 UUD1945, sebuah Perppu yang tidaksecara tegas mendapat persetujuandari DPR "mestinya" tidak dapatdijadikan Undang-Undang atau tidakdapat diteruskan pemberlakuannyasebagai Perppu, tetapi secara politisada fakta yang berkembang sekarangini bahwa "kesemestian" tersebutmasih dipersoalkan, sehingga sebuahPerppu yang tidak disetujui oleh DPR(meski tidak ditolak secara nyata)masih terus diberlakukan sampaidipersoalkan keabsahan hukumnyakarena dikaitkan dengan satu kasus.Dalam keadaan ini menjadi wajarjika Mahkamah diberi kewenanganuntuk melakukan pengujian terhadapPerppu.

Ketiga, Terkait dengan tidak disetujuinyasebuah Perppu oleh DPR ada jugapertanyaan, sampai berapa lama ataukapan sebuah Perppu yang tidakmendapat persetujuan DPR harusdiganti dengan Undang-UndangPencabutan atau UndangUndangPengganti. Karena tidak ada kejelasanbatas atau titik waktu maka dalampengalaman sekarang ini ada Perppuyang tidak mendapat persetujuanDPR.

Keempat, Dapat terjadi suatu saat Perppudibuat secara sepihak oleh Presidentetapi secara politik DPR tidak dapatbersidang untuk membahasnya karenasituasi tertentu, baik karena keadaanyang sedang tidak normal maupunkarena sengaja dihambat dengankekuatan politik tertentu agar DPRtidak dapat bersidang. Bahkan dapatjuga dalam keadaan seperti itu adaPerppu yang melumpuhkan lembagalembaganegara tertentu secarasepihak dengan alasan kegentinganyang memaksa sehingga ada Perppuyang terus dipaksakan berlakunyasementara persidanganpersidanganDPR tidak dapat diselenggarakan.Dengan memerhatikan kemungkinanitu menjadi wajar apabila Mahkamahdiberi kewenangan untuk melakukanpengujian atas Perppu.

Manunggal K. Wardayamengatakan bahwa, penafsiran MK terhadap uji materi Perppu tidak hanya masalah kontestasi penafsiran diantara hakim konstitusi belaka yang merupakan "business as usual” bagi MK sebagai lembaga peradilan, namun juga mengenai perubahan UUD 1945. Dengan menyatakan kewenangannya untuk memeriksa, mengadili, dan memutus Perppu, sesungguhnya MK telah melakukan perubahan pada UUD 1945. mengadili, dan memutus Perppu, sesungguhnya MK 
telah melakukan perubahan pada UUD 1945. MK tidak mengubah rumusan Pasal dalam UUD 1945 yang mengatur mengenai kewenangan MK (dan memang MK bukan lembaga yang berwenang melakukan perubahan UUD sebagaimana telah ditentukan dalam Pasal 3 ayat (1) UUD 1945), namun sebagai the sole interpreter of the constitution MK telah memberi tafsir UUD yang pada esensinya memperluas kewenangan MK dalam memeriksa peraturan perundangan dan oleh karenanya dapat dikatakan merubah UUD 1945. Sebelum dikeluarkan putusan tersebut, kewenangan MK dalam menguji peraturan perundangan terbatas pada peraturan perundangan berupa UU, kewenangan mana selaras secara tekstual dengan UUD 1945 hasil perubahan.Akan tetapi setelah putusan tersebut dikeluarkan, kewenangan konstitusional tersebut menjadi luas yakni termasuk dalam menguji Perpu. ${ }^{20}$

Implikasi dari adanya dissenting opinion berdampak terhadap pemahaman hukum masyarakat, sehingga dengan adanya pemahaman hukum masyarakat dapat mempengaruhi perilaku hukum masyarakat. Dengan pemahaman hukum masyarakat, perilaku masyarakat akan mengikuti hukum yang ada sehingga akan berpengaruh pula terhadap penegakan hukum di Indonesia.

Adanya perubahan perilaku hukum masyarakat yang semakin tertib maka, juga berimplikasi terhadap penegakan hukum. Bahkan jika penegak hukum tidak melakukan penegakan sebagaimana mestinya, maka masyarakat akan mendorong penegak hukum agar dapat melakukan penegakan hukum sebagaimana yang telah ditentukan dalam hukum positif yang berlaku di Indonesia.

\section{E. Kesimpulan}

Dengan uraian mengenai pengujian pengujian Peraturan Pemerintah Pengganti Undang-undang No. 4 Tahun 2009 tentang Perubahan atas Undangundang Nomor 30 Tahun 2002 tentang Komisi Pemberantasan Tindak Pidana Korupsi, yang dilakukan oleh Mahkamah Konstitusi pada Tahun 2009 yang kemudian diputus pada 8 Februari 2010dan memunculkan Dissenting Opiniondari Hakim Muhammad Alim dan Consenting Opinion dari Hakim Mahfud MD. Munculnya

\footnotetext{
${ }^{20}$ Manunggal K. Wardaya."Perubahan Konstitusi Melalui Putusan Mahkamah Konstitusi: Telaah Atas Putusan Nomor 138/Puu-Vii/2009”. Dalam Jurnal Konstitusi. Vol. 7 Nomor 2, April 2010.hlm.39-40
} 
dua hal tersebut (Dissenting Opiniondan Consenting Opinion) setidaknya berimplikasi terhadap dua hal yaitu; pertama, memberikan keleluasaan bagi setiap hakim untuk menggali, mengikuti, dan memahami nilai-nilai hukum dan rasa keadilan yang hidup dalam masyarakat. ${ }^{21}$ Kedua, menjadi bahan evaluasi dan kajian bagi masyarakat untuk mematangkan putusan-putusan hakim yang memang didasarkan terhadap keadilan keadilan substantif.

Putusan Nomor 138/PUU-VII/2009 menunjukkan bahwa, perkembangan putusan Mahkamah Konstitusi tidak hanya berkisar pada Negative Legislature (memutus) namun, telah berkembang kearah Positive Legislature (mengatur). Sehingga, perkembangan putusan Mahkamah Konstitusi berimplikasi terhadap penegakan hukum, untuk memutuskan suatu perkara tidak hanya bertumpu pada adanya teks undang-undang namun, pertimbangan-pertimbangan lain yang melalui penafsiran perundang-undangan sangat dibutuhkan.

\section{DAFTAR PUSTAKA}

Asshiddiqie, Jimly.2006."Hukum Acara Pengujian Undang-undang'Penerbit Konstitusi Press.Jakarta

2008. Menegakkan tiang konstitusi: memoar lima tahun kepemimpinan Prof. Dr. Jimly Asshiddiqie, S.H. di Mahkamah Konstitusi, 2003-2008. Sekretariat Jenderal dan Kepaniteraan, Mahkamah Konstitusi.Jakarta

.2008."Menegakean Tiang Konstitusi Memoar Lima Tabun Kepemimpinan Prof. Dr. Jimly Assbiddiqie, S.H. di Mabkamah Konstitusi (20032008)".Penerbit Sekretariat Jenderal dan Kepaniteraan Mahkamah Konstitusi.Jakarta

Atmadja, I Dewa Gede.2013.'Filsafat Hukun: Dimensi Tematis dan Historis”.Setara Press.Malang

Chandranegara, Ibnu Sina. "Pengujian Perppu Terkait Sengketa Kewenangan Konstitusional Antar Lembaga Negara: Kajian Atas Putusan MK Nomor 138/PUU-VII/2009”. Dalam Jurnal Yudisial.Vol. 5 No. 1, April 2012

Fadjar, A. Mukthie.2008. ”Sang Penggembala, Perjalanan Hidup dan Pemikiran Hukum A. Mukthie Fadjar (Hakim Konstitusi Periode 2003-2008)'.Penerbit Sekretariat Jenderal dan Kepaniteraan Mahkamah Konstitusi.Jakarta

${ }^{21}$ Pasal 5 Ayat (1) UU No. 48 Tahun 2009 
Hadjon, Philipus M, dkk.2008. "Pengantar Hukum Administrasi Negara Indonesia",Gadjah Mada University Press.Yogyakarta

Kamus Besar Bahasa Indonesia.1993.

Magnar, Bagir Manandan Kuntana.1997."Beberapa Masalab Hukum Tata Negara Indonesia".Penerbit Alumni.Edisi Revisi.Bandung

Mamudji, Soerjono Soekanto dan Sri .2006.” Penelitian Hukum Normatif”. Jakarta: Raja Grafindo Persada

Martitah.2013."Mabkamah Konstitusi dari Negative legislature ke Positive Legislature".Konstitusi Press.Jakarta

Marzuki, Peter Mahmud.2014. "Penelitian Hukum. Edisi Revisi". Kencana Prenada Media Group. Jakarta

Matutu, Mustamin DG..dkk, 2004."Mandat, Delegasi, Attribusi Dan Implementasinya Di Indonesid".UII Press.Yogyakarta

MD, Moh. Mahfud.2011."Politik Hukum di Indonesia”. PT. RajaGrafindo Persada.Jakarta

Mertokusumo, Sudikno.2008."'Mengenal Hukum: Suatu Pengantar".Penerbit Liberty.Yogyakarta.Cetakan Keempat

Mertokusumo, Sudikno.2008. "Mengenal Hukum: Suatu Pengantar".Penerbit Liberty.Yogyakarta.Cetakan Keempat .2011.’Teori Hukum”.Universitas Atma Jaya.Yogyakarta

Naskah Komprehensif Perubahan UUD 1945."Latar Belakang, Proses, dan Hasil Pembahasan 1999-2002".Buku VI Kekuasaan Kehakiman.2010

Raharjo, Satjipto.2006. "Imu Hukum".Penerbit PT Citra Aditya Bakti.Bandung.Cetakan Keenam

Salim, Peter Salim dan Yenni.1991.Kamus Besar Bahasa Indonesia.Modern English Press.Jakarta

Soekanto, Sorjono.2002."Faktor-faktor yang Mempengarubi Penegakan Hukum".PT RajaGrafindo Persada

Soimin, Mokhammad Najih.2014."Pengantar Hukum Indonesia: Sejarah, Konsep Tata Hukum, dan Politik Hukum Indonesia".Setara Press.Malang.Edisi Revisi

Subiyanto, Achmad Edi.2014.'Yurisprudensi Hukum Acara dalam Putusan Mabkamah Konstitusi".(Penyunting).Setara Press.Malang

Tacub, M. Dahlan Y. Al-Barry dan L. Lya Sofyan.2003.'Kamus Induk Istilah Ilmiah".Penerbit Target Press.Surabaya.

Thohari, Imam Syaukani dan A. Ahsin.2011.'Dasar-dasar Politik Hukum'.PT. RajaGrafindo Persada.Jakarta

Utrecht, E.1986."Pengantar Hukum Administrasi Negara Indonesia".Pustaka Tinta Mas.Surabaya

Wardaya, Manunggal K..'Perubahan Konstitusi Melalui Putusan Mabkamah Konstitusi: Telaah Atas Putusan Nomor 138/Puu-Vii/2009”. Dalam Jurnal Konstitusi. Vol. 7 Nomor 2, April 2010

Wignjosoebroto, Soetandyo. 2013. 'Hukum Konsep dan Metode”.Setara Press.Malang

Yusa, I Gede (Editor).2011. ’Demokrasi HAM, \& Konstitusi: Perspektif Negara-Bangsa untuk Menghadirkan Keadilan". Kado untuk Sang Guru Prof. Dr. I Dewa Gede Atmadja.Setara Press.Malang

\section{Website}


https://jakarta45.wordpress.com/2009/09/30/perundang-undangan-mk-punyapeluang-uji-perppu-no-42009.diakses 30 Maret 2015

http://infokorupsi.com/id/seminar.php?ac=36\&l=selamatkan-kpk-perppu-42009.diakses 30 Maret 2015.

\section{Perundang-undangan}

Undang-Undang Dasar NRI 1945

Undang - undang Nomor 48 Tahun 2009 tentang Kekuasaan Kehakiman

Undang - undang Nomor 23 Tahun 2003 tentang Mahkamah Konstitusi 